\title{
Identification and Characterization of Supply Chain Operational Risk Profiles in Manufacturing Companies
}

\author{
Hai Thanh Pham * (D) and Chiara Verbano (D)
}

check for updates

Citation: Pham, H.T.; Verbano, C. Identification and Characterization of Supply Chain Operational Risk Profiles in Manufacturing Companies. Sustainability 2022, 14, 1996 https://doi.org/10.3390/su14041996 Academic Editors: Youngwon Park, Takahiro Fujimoto and Paul Hong

Received: 28 December 2021

Accepted: 7 February 2022

Published: 10 February 2022

Publisher's Note: MDPI stays neutral with regard to jurisdictional claims in published maps and institutional affiliations.

Copyright: (C) 2022 by the authors. Licensee MDPI, Basel, Switzerland. This article is an open access article distributed under the terms and conditions of the Creative Commons Attribution (CC BY) license (https:// creativecommons.org/licenses/by/ $4.0 /)$.
Department of Management and Engineering, University of Padova, Stradella San Nicola 3, 36100 Vicenza, Italy; chiara.verbano@unipd.it

* Correspondence: thanhhai.pham@phd.unipd.it

\begin{abstract}
Research on the interactions between risk, integration, and performance in supply chains (SCs) is increasingly attracting attention of researchers in recent years. Although risk usually has negative effects on performance, limited evidence has been provided to show whether companies differently exposed to operational risk (i.e., high, moderate, or low exposure) also have different levels of integration and operational performance. Therefore, this study aims to identify and characterize different profiles of operational risk (i.e., supply, manufacturing, and demand risks) between manufacturing companies along with considering contextual factors such as company size and industry type. Data are collected from the fourth round of the High Performance Manufacturing Project and subsequently analyzed by cluster analysis and analysis of variance (ANOVA). Three different clusters have been identified: Two clusters are moderately and highly impacted by operational risk, respectively, while the other cluster is almost not impacted by manufacturing risk but highly impacted by supply risk and demand risk. The results also indicate that companies with different profiles of operational risk have different levels of integration and operational performance. An important contribution of the current study is the development of a hypothesized framework of interactions between operational risk, integration, and operational performance to provide opportunities for further research.
\end{abstract}

Keywords: operational risk; performance; supply chains; integration; cluster analysis

\section{Introduction}

Supply chains (SCs) are increasingly interdependent and complex. Current trends, for instance, globalization, shortened product life cycle, offshoring, or outsourcing, have made SCs more exposed to risks [1]. Ho et al. [2] admit that risks are always present in SC operations and cause many serious problems for companies, such as suppliers' inability to meet quality requirements, instable manufacturing processes, the bullwhip effect, information distortion, or demand uncertainty. Numerous studies have been performed to quantify the potential impact degree of risks on various performance outputs (e.g., [3-5]), whereas others aim to cover various risks in SCs (e.g., [2,6]). In this case, SC integration is recognized as one of the proactive strategies to minimize the impact of risk [7]. Proactiveness in the SC risk management context refers to detecting probable causes of risk, measuring the risk likelihood and then planning and activating appropriate measures before risks occur [8].

Research on the interactions between risk, integration, and performance in SCs has attracted the attention of scholars, mainly over the past five years. One of the remarkable studies was carried out by Zhao et al. [9]. In the following years, some similar works have been published, whose aims usually focus on two main issues. The first issue is to determine the direction of relationship and the type of impact (i.e., either positive or negative) from risk to integration (e.g., $[9,10])$. The second issue is associated with investigating the moderating effect of risk on the linkage between integration and performance such as [11-13]. Although the above studies have made significant contributions to research on the relationships between risk, integration (i.e., a risk mitigation strategy), and 
performance, they do not show whether companies with different operational risk profiles (i.e., companies are highly, moderately, or lowly impacted by risks) also have varying degrees of integration and operational performance. The word "profile" used in this study denotes the main characteristics of a phenomenon.

The selection of risk mitigation strategy (e.g., SC integration) is based on the supply and demand environments which could be characterized by uncertainty and risk; hence, the impact of risk is dependent on the environmental context of the focal company. For instance, Manuj and Mentzer [14] suggested six risk-management strategies for SCs according to different demand and supply risk environments. This is also confirmed by Knemeyer et al. [15]: Companies that adopt specific risk management practices (e.g., integration) need to be based on both risk impact and likelihood. Furthermore, according to Sharma and Bhat [16], companies having different sizes and operating in different industries could adopt different strategies to mitigate their SC risks. SMEs often have few resources to develop risk mitigation strategies, while large companies have more tools and resources to invest in their SC [17]. Thus, it is argued that companies with different operational risk profiles will develop different levels of integration and achieve different levels of operational performance. The aim of this study is to investigate this hypothesis pursuing the following two objectives: (1) to identify different profiles of operational risk of manufacturing companies at a global level and (2) to characterize these different profiles (if identified) with regard to integration, operational performance, company size, and industry type. Data collected from the High Performance Manufacturing Project will be analyzed by both cluster analysis and ANOVA. It is expected from the results that different operational risk profiles are exposed to different levels of risk impact. Furthermore, higher impact levels of operational risk are related to higher levels of integration and operational performance. In terms of theoretical contribution, this study develops a framework regarding the impacts of operational risk on performance as well as the role of integration in moderating these impacts. In terms of practical contribution, the present study suggests SC managers to apply integration strategies to mitigate the impacts of risk. Regarding limitations, different profiles of operational risk are specifically identified with the involvement of both traditional and world-class manufacturers from High Performance Manufacturing Project.

\section{Literature Review}

\subsection{Supply Chain Risk}

In synthesizing various perspectives from the literature, many scholars (e.g., [2,18]) conclude that SC risks can be classified into two groups: disruption and operational. Disruption risk refers to relatively rare external events. This group of risk encompasses man-made risk (e.g., political instability, terrorism, war) and natural risk (e.g., weather disaster, earthquake). In contrast, operational risk refers to relatively recurrent events stemming directly from internal activities or partnerships in the whole SC. This risk is divided into three subgroups: supply, manufacturing, and demand risks. Supply and demand risks are adverse events at the upstream and downstream SC, respectively [6]. Manufacturing risk is any adverse event within companies which impacts their internal ability to attain timeliness and quality of production, profitability, and good services [19].

While companies better control operational risks by effective treatment measures and risk management, they are more impacted by disruption risks because these risks often go beyond the control and capacity of companies to manage. Risks always have negative impacts on SC processes and activities [20-24]. Byrne [25] notes that disruption risk is less controllable, whereas operational risk is relatively more controllable and can be reduced by effectively managing the SC. Thus, the present study focuses on the impact of operational risk since it is always present in SC activities.

\subsection{Supply Chain Integration}

The understanding of integration requires a clear definition of its constructs [26]. Integration is defined as the strategic collaboration of inter-organizational and intra- 
organizational processes [27]. It consists of two main dimensions: internal and external integrations [28]. Internal integration is defined as the strategic collaboration across functions in companies. It is affirmed collaboration across distribution, production, product design, and procurement functions can satisfy requirements of customers with low costs [29].

External integration consists of customer and supplier integrations. The former refers to information sharing and strategic collaboration between the focal company and its customers with the aim of improving joint planning and visibility. It enables the focal company to understand market expectations and opportunities and quickly responds to customers' requirements by matching supply with demand [30]. Similarly, supplier integration implies strategic collaboration between the focal company and its suppliers to manage inter-organizational processes, for instance, product development, information sharing, and planning [31].

\subsection{Operational Performance}

Manufacturing companies have recognized that competitive advantages can be achieved by establishing partnerships with SC parties. To have those advantages, integrated parties should synchronize processes, as well as build higher levels of coordination [32]. The improvement of operational performance can help manufacturers in enhancing competitive advantage in risk environments, as documented by Zhao et al. [9]. Operational performance is measured by the following dimensions which reflect the capabilities of a company, namely: quality, delivery, flexibility, cost, customer service, and product innovativeness, as outlined by previous works on manufacturing (e.g., $[6,9,11,33]$ ).

\subsection{Interactions between Risk, Integration, and Performance in Supply Chains}

There are three conflicting views in the literature on how SC risk affects the linkage between integration and performance. The first view argues for a negative impact of risk on integration. Indeed, Zhao et al. [9] posit that supply and demand risks are barriers to the establishment of both internal and external integrations. Their study concludes that supply risk negatively impacts all dimensions of integration, while demand risk negatively impacts customer integration. The second view supports a positive impact of risk on integration. Jajja et al. [10] admit that companies facing risk seek to enhance integration among main elements inside (i.e., internal functions) and outside their company (i.e., customers, suppliers). In this regard, risk is a factor that drives companies to develop strategies and actions for risk management.

Finally, the third view supposes that risk moderates the linkage between integration and performance. For instance, Wiengarten et al. [12] hypothesize that weak rules of law (i.e., disruption risk) moderate the strength of the positive relationship between external integration and cost, as well as innovation performance. Moreover, Kauppi et al. [11] examine how country disruption risk is related to the adoption of combined risk management and external integration and how these combinations are related to operational performance. Brusset and Teller [13] argue that operational risk will affect how companies are able to gain benefits from improving capabilities to develop their resilience. With this argument, they examine the moderating effects of supply and demand risks on the linkages between company capabilities (e.g., flexibility, integration) and resilience performance.

Despite the above efforts, one of the questions still remains unanswered: What are the differences between companies regarding the levels of operational risk impact, integration, and operational performance? This study focuses on the impact of operational risk because most of risks in SCs are operational risk [25]. Furthermore, the above studies have not paid enough attention to operational risk. Only Zhao et al. [9], Jajja et al. [10], and Mishra et al. [34] investigate the impact of one or some aspects of operational risk (e.g., supply, manufacturing, or delivery) on SC practices or performance, while the remaining studies (i.e., [12,13]) study the impact of disruption risk such as economic, environmental, social, and political risks. 


\section{Objectives and Methodology}

\subsection{Measurement of Constructs}

To obtain scales that represent seven constructs, a review of the literature was conducted to have measures of constructs. Those measures were subsequently adapted to the database of the High Performance Manufacturing Project to determine items which accurately describe the items' nature attained from the literature. Integration constructs are well verified by previous studies since it is one of the main research directions in SC management. This study applied integration items that are widely used by previous scholars, for example, Wong and Boon-itt [35], Zhao et al. [36], and Qi et al. [37]. The construct of operational performance was operationalized by items adopted by Zhao et al. [9] and Kim [33]. Three constructs of operational risk were newly developed by the present study. Various items are collected from many studies that examine the effect of operational risk. Chen [4] and Vanalle et al. [38] also use this approach to develop scales of risk (e.g., demand, manufacturing, and supply risks). Reversed scale was also applied to the three constructs of operational risk, as suggested by Zhao et al. [9]. The items of operational risk, integration, and operational performance are listed in Tables 1 and 2.

Table 1. Items of operational risks.

\begin{tabular}{|c|c|c|c|}
\hline Construct & Items from Literature & Items from HPM Project & References \\
\hline \multirow{5}{*}{$\begin{array}{l}\text { Supply risk } \\
\text { (reversed scale) }\end{array}$} & Supplier opportunism & $\begin{array}{l}\text { Our suppliers fairly treat us in making } \\
\text { important decisions. }\end{array}$ & [1] \\
\hline & Late delivery & $\begin{array}{l}\text { Our suppliers deliver to us on a } \\
\text { just-in-time basis. }\end{array}$ & [39] \\
\hline & Small supply base & $\begin{array}{l}\text { Our supply base is quite small, compared } \\
\text { with our competitors. }\end{array}$ & [40] \\
\hline & $\begin{array}{l}\text { Different business vision, style, and } \\
\text { bureaucracy degree between the two } \\
\text { parties result in cost increase }\end{array}$ & $\begin{array}{l}\text { Partners understand our goals for supply } \\
\text { chain management. }\end{array}$ & [41] \\
\hline & Supplier incapability & $\begin{array}{l}\text { Partners understand that we expect them to } \\
\text { continuously improve their supply } \\
\text { chain operations. }\end{array}$ & [42] \\
\hline \multirow{3}{*}{$\begin{array}{l}\text { Manufacturing risk } \\
\text { (reversed scale) }\end{array}$} & Strategy-related manufacturing risk & $\begin{array}{l}\text { Manufacturing strategy is not } \\
\text { effectively implemented. }\end{array}$ & [43] \\
\hline & Human-related manufacturing risk & $\begin{array}{l}\text { Operators detect and treat abnormal } \\
\text { operating conditions of equipment. }\end{array}$ & [44] \\
\hline & $\begin{array}{l}\text { Technology/Equipment-related } \\
\text { manufacturing risk }\end{array}$ & $\begin{array}{l}\text { There is no substitute for our } \\
\text { production technology. }\end{array}$ & [44] \\
\hline \multirow{4}{*}{$\begin{array}{l}\text { Demand risk } \\
\text { (reversed scale) }\end{array}$} & $\begin{array}{l}\text { The number of not-on-time deliveries } \\
\text { represents potential future delays }\end{array}$ & We always deliver on time to our customers. & [45] \\
\hline & Sudden production stoppages & $\begin{array}{l}\text { We can adapt our production schedule to } \\
\text { sudden production stoppages by } \\
\text { our customers. }\end{array}$ & [19] \\
\hline & Deficient customer linkage and attraction & $\begin{array}{l}\text { Our customers are connected to us by } \\
\text { JIT systems. }\end{array}$ & [44] \\
\hline & Unreliable demand information & $\begin{array}{l}\text { Our customers provide us with valuable } \\
\text { information on product innovation. }\end{array}$ & [35] \\
\hline
\end{tabular}


Table 2. Items of supply chain integration and operational performance.

\begin{tabular}{|c|c|c|c|}
\hline Construct & Items from Literature & Items from HPM Project & References \\
\hline Supplier integration & $\begin{array}{l}\text { Product integration } \\
\text { Process integration } \\
\text { Information integration } \\
\text { Strategic integration }\end{array}$ & $\begin{array}{l}\text { Our suppliers are provided with sufficient } \\
\text { technical assistance. } \\
\text { Meetings are regularly held to share improvement ideas } \\
\text { with our suppliers. } \\
\text { Our suppliers are encouraged to continuously improve } \\
\text { their production processes. } \\
\text { Our suppliers are asked to invest in significant } \\
\text { process improvement. } \\
\text { Necessary trainings are offered to our suppliers. } \\
\text { Our vision and supply chain policy are shared } \\
\text { with suppliers. } \\
\text { Assistance is provided when our suppliers try to } \\
\text { improve their processes }\end{array}$ & [35-37] \\
\hline Internal integration & $\begin{array}{l}\text { Functional integration } \\
\text { Strategic integration }\end{array}$ & $\begin{array}{l}\text { Functions are well integrated in our plant. } \\
\text { Problems between functions are easily solved. } \\
\text { Functional coordination in our plant works well. } \\
\text { Our business strategy is implemented without conflicts } \\
\text { between functions. }\end{array}$ & [35-37] \\
\hline Customer integration & $\begin{array}{l}\text { Product integration } \\
\text { Process integration } \\
\text { Information integration } \\
\text { Strategic integration }\end{array}$ & $\begin{array}{l}\text { We are concerned about needs of both immediate and } \\
\text { ultimate consumers. } \\
\text { We understand marketing strategies of customers. } \\
\text { We are very familiar with product characteristics } \\
\text { of customers. } \\
\text { We understand distribution processes of customers. }\end{array}$ & [35-37] \\
\hline Operational performance & $\begin{array}{l}\text { Manufacturing cost } \\
\text { Quality } \\
\text { On time delivery } \\
\text { Flexibility } \\
\text { Product launch } \\
\text { Innovativenes } \\
\text { Customer service }\end{array}$ & $\begin{array}{l}\text { Unit cost of manufacturing } \\
\text { Conformance to product specifications } \\
\text { On time delivery performance } \\
\text { Flexibility to change product mix } \\
\text { Flexibility to change volume } \\
\text { On time new product launch } \\
\text { Product innovativeness } \\
\text { Customer support and service }\end{array}$ & {$[9,33]$} \\
\hline
\end{tabular}

\subsection{Data Collection: High Performance Manufacturing Project}

The data for the present study were collected from the fourth round of the High Performance Manufacturing Project, which is a secondary database with the support of various research teams from universities in many countries. The 303 surveyed plants have a minimum number of 100 employees and belong to 3 industries, automotive $(n=79)$, machinery $(n=110)$, and electronics $(n=114)$, in 3 continents, Europe (Germany, Spain, Sweden, Italy, Finland, United Kingdom), Asia (Israel, Japan, China, Korea, Taiwan, Vietnam), and America (Brazil) (Table 3). The analysis unit in this project is a manufacturing plant rather than company because differences could exist in production practices, performance, and contextual factors among plants belonging to the same company. In addition, all plants in a particular country come from different parent corporations. According to Naor et al. [46], this analysis unit could provide a full understanding of practices as well as the performance of manufacturing plants. These industries were selected because they operate in a globally competitive environment and face very high competition. The selection of plants was also limited to countries that are known for their strengths in manufacturing. Plants in these countries are either world-class manufacturers (i.e., high performers) or traditional manufacturers (i.e., standard performers) [47]. Indeed, nearly one half of plants were randomly selected from lists of "world class reputation" plants extolled as leaders by industry experts. This is to ensure that the database contains a good representation of the best plants in the world. The other half of the plants were selected from lists of standard plants. Moreover, 
plants were randomly selected with a number of 10 plants for each industry, hence, nearly 30 plants in each country.

Table 3. Sample profile (number of plants by country and industry).

\begin{tabular}{ccccc}
\hline \multirow{2}{*}{ Country } & \multicolumn{3}{c}{ Industry Sector } & Total \\
\cline { 2 - 4 } & Electronics & Machinery & Automotive & 21 \\
Brazil & 5 & 7 & 9 & 28 \\
Germany & 6 & 13 & 9 & 25 \\
Spain & 8 & 7 & 10 & 26 \\
Israel & 21 & 5 & 0 & 9 \\
Sweden & 4 & 4 & 1 & 29 \\
Italy & 7 & 17 & 5 & 23 \\
Japan & 6 & 7 & 10 & 30 \\
China & 10 & 17 & 3 & 26 \\
Korea & 8 & 5 & 13 & 17 \\
Finland & 6 & 6 & 5 & 30 \\
Taiwan & 19 & 5 & 1 & 13 \\
United Kingdom & 4 & 7 & 4 & 26 \\
Vietnam & 10 & 110 & 9 & 303 \\
Total & 114 & & 79 &
\end{tabular}

Items of the questionnaires were gathered from the literature of operations management. All instruments were reviewed to ensure the content validity, and a pilot test was conducted at several plants with pre-tests, which were subsequently analyzed for reliability and internal consistency. Twelve questionnaires were answered by different managerial positions, and in total, twenty-three questionnaires were conducted at each plant. Many questions were mentioned in at least two different questionnaires to attain the information triangulation, as well as to minimize variability caused by different participants' perceptions, thus, the reliability of scales can be guaranteed. Furthermore, items composing scales were combined in different ways in each questionnaire to prevent data bias [48].

\section{Results}

As mentioned above, the current study is performed to investigate the hypothesis whether companies with different operational risk profiles also have different levels of integration and operational performance. This study also further characterizes operational risk profiles through the consideration of industry type and company size. With regard to industry type, different industries may have different SC characteristics and practices [16]. There are three industries involved in the High Performance Manufacturing Project, including the electronics, machinery, and automotive industries; thus, the current study will examine differences in operational risk profiles regarding these manufacturing industries. More importantly, the inclusion of company size is supported by the argument on different SC roles and practices between large companies and SMEs. According to Arend and Wisner [49], the size of a company influences advantages achieved from the management of its SC.

Cluster analysis is an exploratory technique employed to identify distinct patterns or groups of a dataset [50]. One of the most widely used methods for cluster analysis is k-means clustering. This method has been applied in many research areas because of its advantages, for instance, ease of implementation, simplicity, and efficiency [51]. In this study, the k-means clustering method is used to group 303 cases in the High Performance Manufacturing database into homogeneous categories in consideration of operational risk aspects with the aim of identifying different profiles of operational risk. Clusters are validated by using ANOVA to test whether there are significant differences in mean values of the constructs across clusters.

Using operational risk constructs as clustering variables, three homogeneous clusters of cases with different profiles are obtained by applying the k-means method. Clustering 
with solutions of 4, 5, and 6 clusters is also conducted, but these solutions are not chosen due to two reasons: First, the mean values of the operational risk constructs are not really different, and second, the resulting number of cases distributed between the clusters of these solutions are not acceptable (too different). With the solution of three clusters, observations of the database are equally allocated between three clusters (cluster 1: $n=101$; cluster 2: $n=116$; cluster 3: $n=86$ ). The result shows that all F-statistics are significant at the level of 0.01 (Table 4); thus, three clusters have differences in mean values of operational risk constructs. In other words, different operational risk profiles are exposed to different levels of risk impact. Therefore, it is concluded supply, manufacturing, and demand risks have significant impacts on determining which cluster a case is allocated to.

Table 4. ANOVA of operational risks.

\begin{tabular}{ccccccc}
\hline \multirow{3}{*}{ Supply risk } & \multicolumn{1}{c}{$\begin{array}{c}\text { Sum of } \\
\text { Squares }\end{array}$} & df & $\begin{array}{c}\text { Mean } \\
\text { Square }\end{array}$ & F & Sig. \\
\hline \multirow{3}{*}{ Manufacturing risk } & Between Groups & 25.213 & 2 & 12.607 & 59.580 & 0.000 \\
\cline { 2 - 7 } & Within Groups & 63.477 & 300 & 0.212 & & \\
\cline { 2 - 7 } & Total & 88.691 & 302 & & & \\
\cline { 2 - 7 } & Wetween Groups & 77.316 & 2 & 38.658 & 206.031 & 0.000 \\
\cline { 2 - 7 } & Tithin Groups & 56.289 & 300 & 0.188 & & \\
\hline \multirow{3}{*}{ Demand risk } & Between Groups & 65.005 & 2 & 32.502 & 151.208 & 0.000 \\
\cline { 2 - 7 } & Within Groups & 64.485 & 300 & 0.215 & & \\
\cline { 2 - 7 } & Total & 129.490 & 302 & & & \\
\hline
\end{tabular}

In addition, ANOVA is used to test whether there are significant differences in mean values of integration and operational performance constructs between the three identified clusters. It is seen that F-statistics are significant at the level of 0.01 (Table 5), so three clusters have differences in mean values of integration and operational performance constructs. In other words, the three clusters also have different levels of integration and operational performance.

Table 5. ANOVA of supply chain integration and operational performance.

\begin{tabular}{|c|c|c|c|c|c|c|}
\hline & & $\begin{array}{l}\text { Sum of } \\
\text { Squares }\end{array}$ & df & $\begin{array}{l}\text { Mean } \\
\text { Square }\end{array}$ & $\mathbf{F}$ & Sig. \\
\hline \multirow{3}{*}{ Supplier integration } & Between Groups & 11.637 & 2 & 5.819 & 20.532 & 0.000 \\
\hline & Within Groups & 85.018 & 300 & 0.283 & & \\
\hline & Total & 96.655 & 302 & & & \\
\hline \multirow{3}{*}{ Internal integration } & Between Groups & 9.518 & 2 & 4.759 & 13.411 & 0.000 \\
\hline & Within Groups & 106.452 & 300 & 0.355 & & \\
\hline & Total & 115.969 & 302 & & & \\
\hline \multirow{3}{*}{$\begin{array}{l}\text { Customer } \\
\text { integration }\end{array}$} & Between Groups & 12.110 & 2 & 6.055 & 18.398 & 0.000 \\
\hline & Within Groups & 98.736 & 300 & 0.329 & & \\
\hline & Total & 110.847 & 302 & & & \\
\hline \multirow{3}{*}{$\begin{array}{l}\text { Operational } \\
\text { performance }\end{array}$} & Between Groups & 4.322 & 2 & 2.161 & 10.534 & 0.000 \\
\hline & Within Groups & 61.537 & 300 & 0.205 & & \\
\hline & Total & 65.859 & 302 & & & \\
\hline
\end{tabular}


Mean values of all constructs are shown in Figure 1. Cluster 1 is mildly impacted by operational risks and has a low level of both integration and operational performance. Cluster 3 is moderately impacted by operational risks and has moderate integration and operational performance. Notably, cluster 2 is almost not impacted by manufacturing risk but is highly impacted by supply risk and demand risk, and this cluster has high integration and operational performance as compared to clusters 1 and 3 . This result supports the argument that higher impact levels of operational risk are associated with higher levels of integration and operational performance.

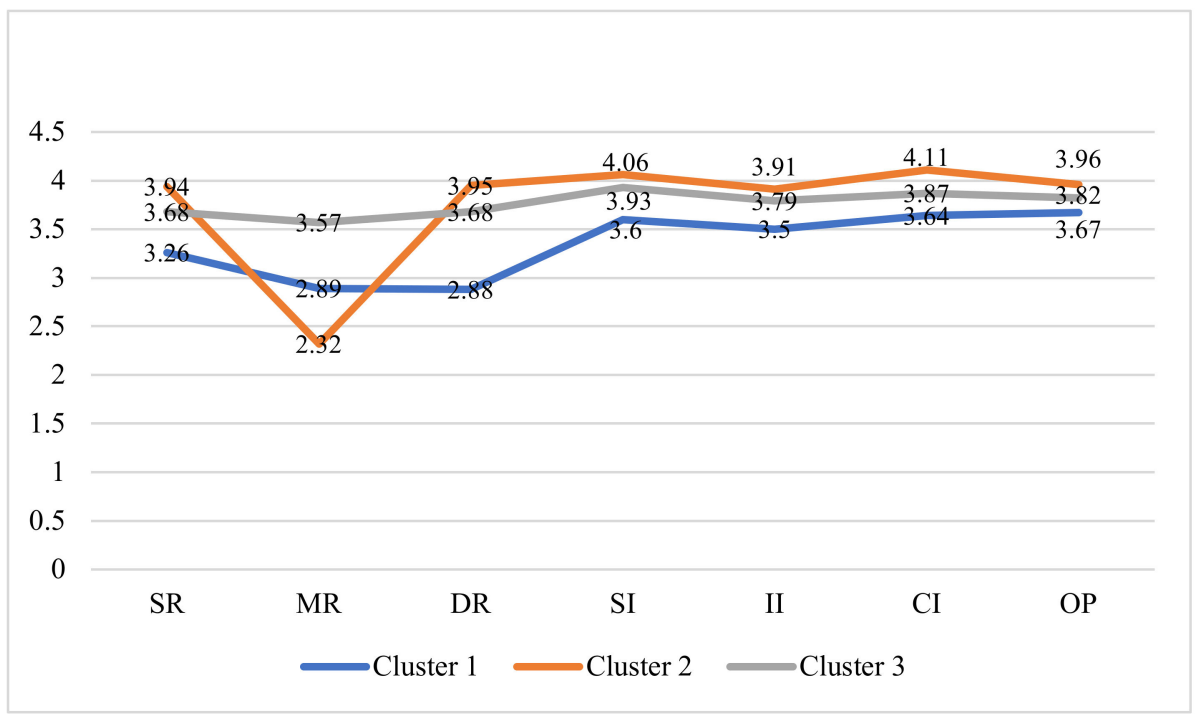

Figure 1. Mean values of all constructs. Note: SR: supply risk; MR: manufacturing risk; DR: demand risk, SI: supplier integration; II: internal integration; CI: customer integration; OP: operational performance.

In order to enhance the practical significance of the three clusters, they are further profiled by using contextual factors, namely, industry type and company size. There are three industries in the High Performance Manufacturing database, including the automotive, machinery, and electronics industries. Company size is classified based on the employee number as micro (employees $<10)$, small $(10 \leq$ employees $<50)$, medium $(50 \leq$ employees $<250)$, and large (employees $\geq 250)$ [52]. High Performance Manufacturing is a secondary database, including only companies with more than 100 employees. For this reason, micro and small companies are not included in analyses. The result shows that significant values of the chi-squared test support the associations between the impact levels of operational risk (i.e., three clusters) and industry type (chi-squared test is significant at 0.021 ) as well as company size (chi-squared test is significant at 0.048). From Figure 2, it is seen that large companies are mostly in cluster 2, while medium companies almost all belong to cluster 1. In Figure 3, the electronics and automotive industries are mainly distributed into cluster 2 while machinery industry mostly belongs to cluster 1 . Table 6 presents the results obtained from cluster analysis and ANOVA of the current study. 


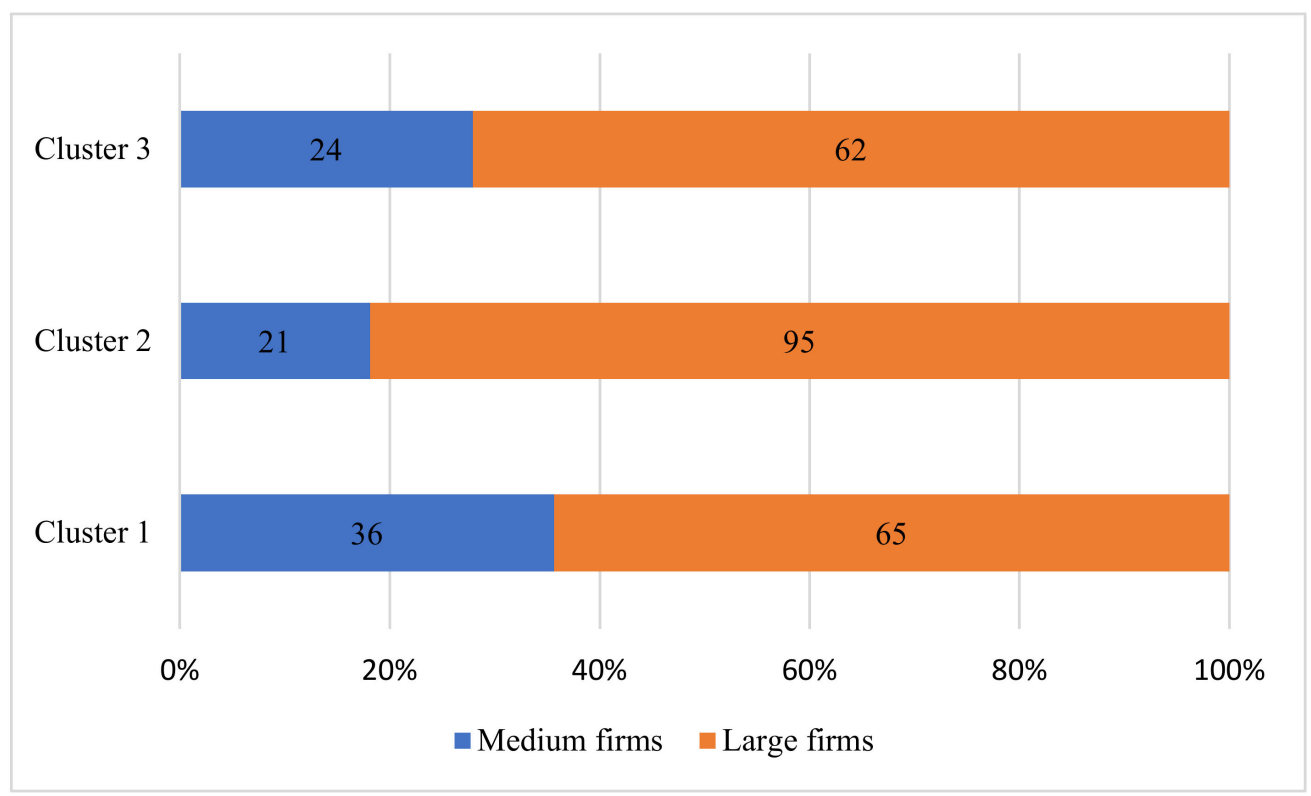

Figure 2. Profiling of three clusters based on company size.

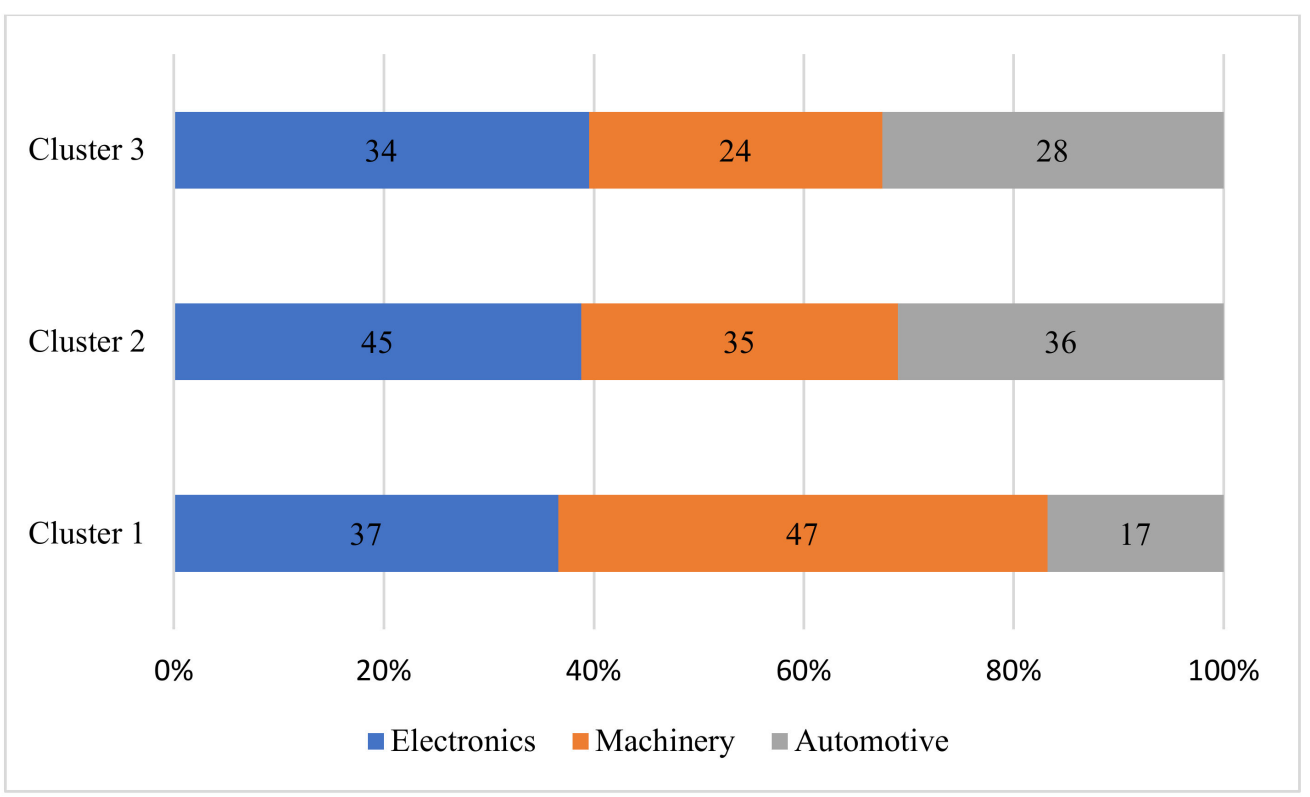

Figure 3. Profiling of three clusters based on industry type.

Table 6. Main characteristics of operational risk profiles.

\begin{tabular}{|c|c|c|c|c|c|}
\hline Cluster & Operational Risks & $\begin{array}{l}\text { Supply Chain } \\
\text { Integration }\end{array}$ & $\begin{array}{l}\text { Operational } \\
\text { Performance }\end{array}$ & Industry Type & Company Size \\
\hline 1 & $\begin{array}{c}\text { Low supply risk } \\
\text { Low manufacturing risk } \\
\text { Low demand risk }\end{array}$ & Low & Low & $\begin{array}{c}\text { Electronics }(37 \%, n=37) \\
\text { Machinery }(46 \%, n=47) \\
\text { Automotive }(17 \%, n=17)\end{array}$ & $\begin{array}{c}\text { Medium }(36 \%, n=36) \\
\text { Large }(64 \%, n=65)\end{array}$ \\
\hline 2 & $\begin{array}{l}\text { High supply risk } \\
\text { Low manufacturing risk } \\
\text { High demand risk }\end{array}$ & High & High & $\begin{array}{c}\text { Electronics }(39 \%, 45) \\
\text { Machinery }(30 \%, 35) \\
\text { Automotive }(31 \%, 36)\end{array}$ & $\begin{array}{l}\text { Medium }(18 \%, 21) \\
\text { Large }(82 \%, 95)\end{array}$ \\
\hline 3 & $\begin{array}{l}\text { Moderate supply risk } \\
\text { Moderate manufacturing risk } \\
\text { Moderate demand risk }\end{array}$ & Moderate & Moderate & $\begin{array}{c}\text { Electronics }(39 \%, 34) \\
\text { Machinery }(28 \%, 24) \\
\text { Automotive }(33 \%, 28)\end{array}$ & $\begin{array}{l}\text { Medium }(28 \%, 24) \\
\text { Large }(72 \%, 62)\end{array}$ \\
\hline
\end{tabular}




\section{Discussion}

Previous studies (e.g., [10]) have supposed that the presence of risk results in the development of integration which is aimed at maintaining a competitive advantage. It means that risk will drive organizational strategies and actions for managing risks [53]. They argue that risk management is not really imperative with the absence of risk. This view is no longer appropriate because in the current globalization, manufacturers often cooperate with suppliers and customers, so supply and demand risks always occur in SC activities [18]. In this regard, companies need to develop external integration to deal with these two risks. However, in order to develop external integration, first of all companies have to develop internal integration within their company. This conclusion is underpinned by the findings of Jajja et al. [10] when they explain that internal integration provides the support for both supplier and customer integrations [54], which in turn have positive effects on performance. External integration always plays a fundamental role in maintaining operational performance of SCs. Additionally, the impacts of supply and demand risks will not be mitigated if companies do not have high external integration. For example, with integrated relationships with suppliers, activities and processes of the focal company are directly related to those of suppliers. In order to ensure the products' quality, companies can assist suppliers in implementing quality management programs. As a result, operations of both sides are better coordinated, and then supply risk is mitigated [55]. Similarly, in collaborative relationships, customers are able to share reliable and timely demand information to manufacturers. Sharing information about consumer preferences and market trends also enables manufacturers to better understand requirements of customers and enhance the accuracy of demand forecasting [56].

Our findings support the argument that companies (i.e., cluster 2) still need to establish internal integration even in situations they do not face high manufacturing risk because supplier and customer integrations could not be well developed if companies have a low internal integration. In this case, internal integration acts as a driver of external integration. This is the reason why cluster 2 not highly affected by manufacturing risk still has high integration and operational performance. The findings also support the hypothesis clusters that are more exposed to operational risk (i.e., clusters 2 and 3) have stronger integration and operational performance. Specifically, cluster 2 has high integration with partners and high operational performance while companies in cluster 1 integrate at the low level and have low operational performance. An explanation for the profile of cluster 1 may be that companies having low level of integration also face less risks while companies with strong integration will face more risks. Indeed, at the global level companies often cooperate with many suppliers and build distribution centers and manufacturing factories in many countries because of reasons such as access to raw material sources and cost advantages [57]. This is also concluded by [14] that global configurations of companies can provide larger product markets, better financing opportunities, and cheap labor. However, the current globalization along with collaboration with numerous suppliers and customers also pose numerous risks to SCs (e.g., increasing complexity) [18].

Furthermore, this study also concludes that there are differences between clusters (i.e., different impact levels of risk) related to sizes of company. Research on the risk impacts on performance has argued that companies with different sizes will have different SC practices and particularly have different exposures to risk, as well as different risk mitigation strategies [16]. Based on the ANOVA test, there are significant differences $(p<0.05)$ in mean values of supply risk and manufacturing risk between medium and large companies in cluster 2 and cluster 3 . Furthermore, the mean value of the manufacturing risk of medium companies is found to be higher than that of large companies. This shows that medium companies are more affected by manufacturing risk than large companies. A possible explanation for this may be due to the fact that large companies usually own many resources to invest in their SC, whereas SMEs have limited resources to build risk-mitigation strategies (e.g., integration), hence they are also strongly affected by risks [17]. 
It is observed from Table 6 that all companies in three clusters are medium and large companies. Since the chi-squared test is found to be significant, it can be concluded that there are differences between three clusters regarding company size. It is also seen that there are significant differences across the clusters according to different industries. Sharma and Bhat [16] note that companies in the same industry often exhibit the same strategic perspective while companies in different industries will have different strategic perspectives.

\section{A Guiding Framework for Empirical Investigation}

The current study is exploratory in nature, hence the relationships between operational risk, integration, and operational performance have not yet been confirmed even though the three clusters are well-differentiated in relation to integration, operational performance, company size, and industry type. Therefore, the aim of this section is to develop a theoretical framework to guide further studies in examining interactions between operational risk, integration, and operational performance. This framework is built since the literature has limited evidence about interactions between these constructs. Moreover, several researchers such as Zhao et al. [9] and Wong and Boon-itt [35] argue that research on the linkage between SC risk and integration has been scarce.

The role of integration in mitigating the impact of operational risk and sustaining operational performance is still unconfirmed; yet, from the findings and Figure 1, it may be that integration has such a role since the literature (e.g., [58,59]) concludes that integration can decrease the influence of risk and enhance performance. Indeed, in Figure 1, the three clusters facing different levels of risk impact have different levels of operational performance. There may be some factors that moderate the relationship between SC risk and performance, for example, Qazi et al. [60] and Macdonald et al. [61] investigate the moderating roles of SC risk management process and investments in resilience, respectively, on the linkages between risks (both operational and disruption) and various performance measures. However, since this study's focus is about interactions between operational risk, integration, and operational performance; integration is considered as one of such factors.

There are three different perspectives in the literature pertaining to the impact of risk on the linkage between integration and performance. The first perspective argues risk is a factor that hinders integration among partners, for instance, Zhao et al. [9] conclude that supply and demand risks are two barriers to the development of internal and external integrations. The second perspective supports the positive effect of risk on integration. Indeed, Jajja et al. [10] confirm that risk will promote organizational strategies for managing risks because in low-risk environments, risk management is not really imperative. In this situation, integration is considered as a reactive risk mitigation strategy in overcoming risk consequences because integration is just developed after the appearance of risk. The third perspective affirms that risks moderate the relationships between integration and performance, such as in [11-13].

However, one of the main limitations of all perspectives is that they do not show the direct effects of risk on performance. Moreover, these studies have not yet demonstrated the simultaneous effects of integration on risk and performance. Different from these three perspectives, the current study argues that integration should act as moderators by which the negative effects of operational risk on operational performance could be reduced (Figure 4). The hypotheses that support relationships are presented below. It is noted that the first three hypotheses (i.e., H1, H2, and H3) are associated with the effects of operational risk, while the remaining three hypotheses (i.e., H4, H5, and H6) focus on the moderating effects of integration. 


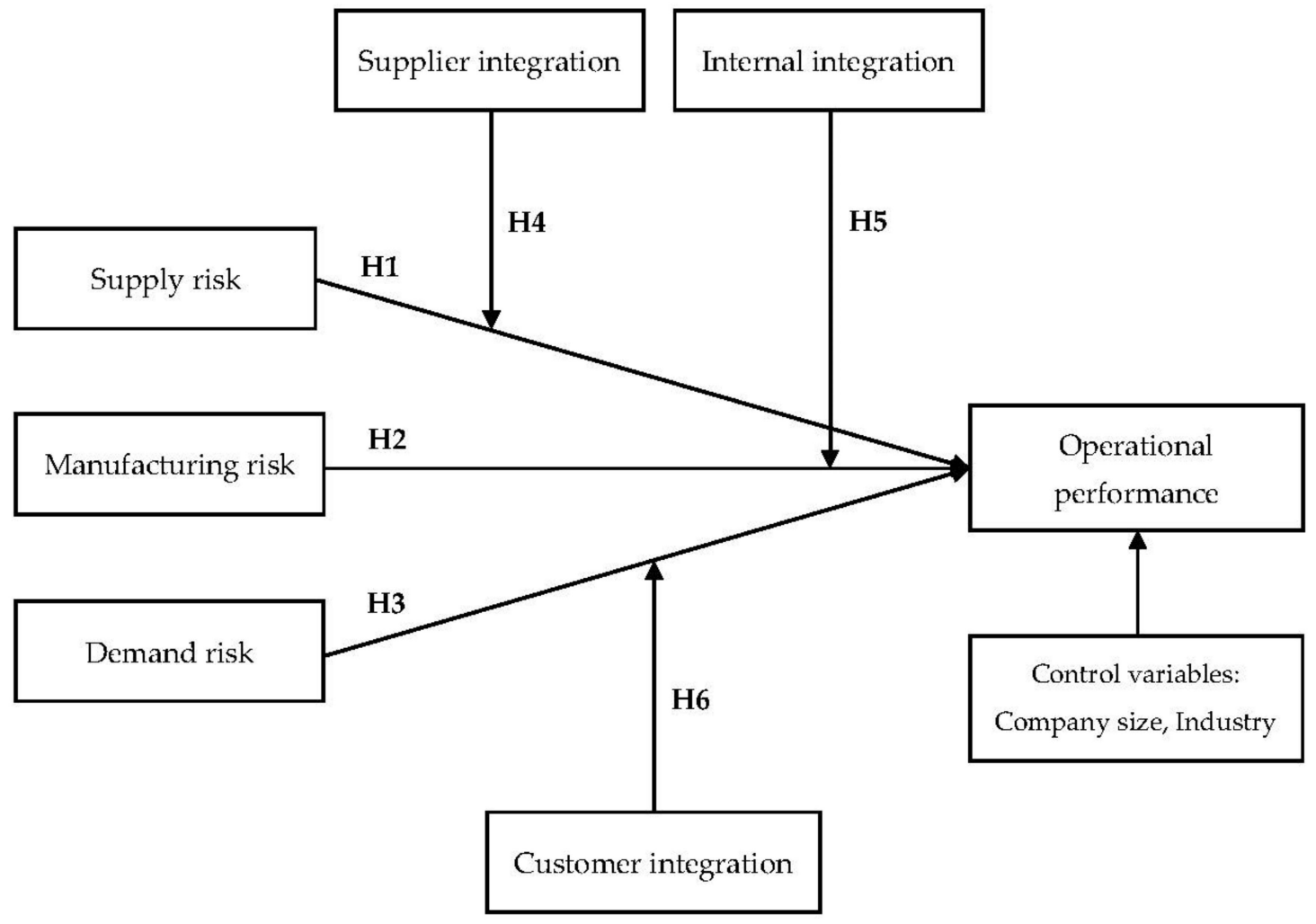

Figure 4. The hypothesized framework.

Inconsistency in suppliers' performance makes the performance of the focal company unpredictable and increases the appearance of supply risk. According to Zsidisin and Ellram [62], there are many risks which can impact performance of suppliers such as late delivery, low quality, or shortage of quantity. These risks will interrupt the supply side regarding quality, quantity, and supply lead time. Because focal companies rely on suppliers in maintaining manufacturing processes, suppliers' inability to deliver products and materials has adverse impacts on the SC's ability to serve customers.

H1: Supply risk negatively affects operational performance.

There are two main types of risk in a manufacturing system. The first type refers to detractors, for instance, the unavailability of operators, setups, or machine downtime, while the second type is mainly caused by the way works are released to the system as well as the movement between stations [63]. These manufacturing risks lead to inconsistency in quality of products, process yield, and throughput time, as well as make the performance of the manufacturing process unpredictable.

H2: Manufacturing risk negatively affects operational performance.

The basic aim of SCs is to match supply with demand, yet unexpected changes in demand decrease the forecast accuracy and make it hard to achieve this aim [64]. Order changes could result from a shorter life cycle of products and the introduction of new products to the market [1]. The mismatch between forecast and actual orders can reduce both the effectiveness and efficiency of SCs. In some situations, even though the demand pattern is flat and the market demand is stable, the bullwhip effect still amplifies demand signal and increases order variability [65]. For these reasons, demand risk is a real threat to companies in serving customers.

H3: Demand risk negatively affects operational performance.

Paulraj and Chen [66] note that commitment in partnerships can help suppliers extend cooperation with manufacturers even in risky environments. Partnerships also enable manufacturers to leverage resources and reconfigure capabilities of suppliers to mitigate the risk impact [58]. By developing supplier integration, focal companies can share order 
and inventory information to suppliers; this is to help suppliers deliver materials and components on time and ensure product quality [67]. Many researchers (e.g., [68]) posit that supplier integration can reduce upstream risks which adversely affect schedule attainment of manufacturers. Furthermore, Chaudhuri et al. [59] emphasize that supplier integration can also help manufacturers mitigate the impact of other supply risks, for instance, inability to respond to demand changes, lack of supplier commitment, unavailability in information flow, and supply delay.

H4: Supplier integration moderates the linkage between supply risk and operational performance.

An effective internal environment will improve the ability of companies in determining risks and shortening the consequences' duration [69]. Teece et al. [70] state that in a dynamic environment, manufacturers constantly scan the SC environment and then share information among functional units. By internal integration, knowledge will be effectively generated and transferred inside their company [71]. Experts from various functions can work together as a team to satisfy customers' requirements, particularly for improvement in product quality and new product development. Furthermore, the cooperation of various functions helps companies solve conflicts, enhance flexibility, and improve delivery speed to customers.

H5: Internal integration moderates the linkage between manufacturing risk and operational performance.

When the focal company closely works with customers, its manufacturing schedule can be more accurate, and this will reduce the risk of frequent schedule changes. Moreover, the risk of the bullwhip effect is mitigated through information sharing and cooperation between the focal company and customers. These two partners can coordinate to jointly develop an understanding of demand as well as replenishment plans to meet customer requirements efficiently [72]. Lau et al. [58] and $\mathrm{Hu}$ et al. [73] advise that manufacturing companies need to have attempts in integrating their activities with those of customers because an understanding of both customer demand and product delivery mechanism will assist them in predicting behaviors of customers and delivery challenges in unusual situations.

H6: Customer integration moderates the linkage between demand risk and operational performance.

\section{Implications}

\subsection{Theoretical Implications}

The present study makes some theoretical contributions to research on interactions between operational risk, integration, and operational performance in relation to different industries and company sizes. ANOVA shows that companies with different sizes are differently affected by operational risk and also develop different levels of integration (i.e., a SC practice). Although the literature has argued for differences between SMEs and large companies regarding SC practices, limited evidence has been provided in demonstrating these differences (e.g., [10]). For example, Sharma and Bhat [16] assume that companies with different sizes will have different SC risk management levels, yet they cannot prove these differences. In contrast, the current study confirms that SMEs and large companies are differently exposed to operational risk, develop different levels of integration, and achieve different operational performance. Another important theoretical contribution of this study is the development of a hypothesized framework regarding the effects of operational risk on operational performance, as well as the role of integration in moderating these effects. This hypothesized model could guide future studies in carrying out theory-testing research through large-scale data such as surveys.

\subsection{Practical Implications}

In terms of practical implications, the findings show that companies that are more exposed to operational risk also have higher integration and operational performance. 
Moreover, companies need to develop integration strategies, especially internal integration, because of their positive effects. First, integration will help to minimize the negative effects of operational risk. When the environment becomes more turbulent, companies have to adopt some strategies to cope with unexpected outcomes [74]. In the presence of environmental uncertainty, companies should have a strategy in order to decrease the risk impacts and unexpected outcomes, and achieve stability of business operations [75]. One of such strategies should be integration. In this regard, SC managers need to apply this strategy to reduce the impacts of risk. Second, integration with suppliers and customers has been recognized as one of the main competitive differentiators for companies (e.g., [76]). Consistent with this evidence, this study concludes that SC managers need to develop integrated strategies to achieve higher levels of operational performance. Third, internal integration is a driver of external integration, meaning that internal integration provides the support for external integration, which in turn positively affects performance (e.g., [77]). It is reported that external integration amplifies the effect of internal integration on operational performance [54]. For this reason, companies have to develop internal integration before heading toward external integration because the effectiveness of external integration will not be achieved if companies do not have a high internal integration.

\section{Conclusion and Limitations}

Although research on the interactions between risk, integration, and performance in SCs is increasingly attracting interest from researchers, it is still unclear whether companies with different profiles of operational risk could have different levels of integration and operational performance. This argument has not yet been confirmed by the literature. In order to fill this gap, the present study aims to identify and characterize different operational risk profiles along with considering contextual factors that help to further distinguish those profiles, namely, integration, operational performance, company size, and industry type. Cluster analysis and ANOVA are used to analyze data collected from the fourth round of the High Performance Manufacturing Project.

The results indicate that three different clusters of companies have been identified: cluster 1 and cluster 3 are lowly and moderately affected by all operational risks, respectively, whereas cluster 2 is lowly impacted by manufacturing risk but highly impacted by supply and demand risks. It is surprising that three clusters have different levels of integration and operational performance. Specifically, cluster 1 and cluster 3 have low and moderate integration and operational performance, respectively, while cluster 2 has high integration and operational performance. Furthermore, these clusters are further profiled by using contextual factors such as company size and industry type.

From the literature analysis, this study argues that integration could play a moderating role in the relationship between operational risk and operational performance. Therefore, the study develops a framework in which the linkages (including direct and moderating effects) between operational risk, integration, and operational performance have been hypothesized. Direct and moderating effects of the framework could be examined by using regression analyses. Through this framework, differences in impacts of operational risk and integration on operational performance between SMEs and large companies could be further studied. However, since High Performance Manufacturing Project is a global project with the involvement of numerous traditional and world-class manufacturers, different profiles of operational risk have been discovered by this study. Further studies should be cautious in testing our framework's hypotheses, especially those conducted without a large sample size or conducted in a specific country where there is a limited number of world-class manufacturers.

Author Contributions: H.T.P. and C.V. contributed to the development of this study, specifically its conceptualization, methodology, validation, analysis, writing, review and editing, and project administration. All authors have read and agreed to the published version of the manuscript.

Funding: This research and the APC were funded by the University of Padova, Grant VERB_SID19_01. 
Institutional Review Board Statement: Not applicable.

Informed Consent Statement: Not applicable.

Data Availability Statement: Not applicable.

Conflicts of Interest: The authors declare no conflict of interest.

\section{References}

1. Manuj, I.; Mentzer, J.T. Global Supply Chain Risk Management. J. Bus. Logist. 2008, 29, 133-155. [CrossRef]

2. Ho, W.; Zheng, T.; Yildiz, H.; Talluri, S. Supply chain risk management: A literature review. Int. J. Prod. Res. 2015, 53, 5031-5069. [CrossRef]

3. Macdonald, J.R.; Corsi, T.M. Supply Chain Disruption Management: Severe Events, Recovery, and Performance. J. Bus. Logist. 2013, 34, 270-288. [CrossRef]

4. Chen, H.L. Supply chain risk's impact on corporate financial performance. Int. J. Oper. Prod. Manag. 2018, 38, 713-731. [CrossRef]

5. Quang, H.T.; Hara, Y. Risks and performance in supply chain: The push effect. Int. J. Prod. Res. 2017, 56, 1369-1388. [CrossRef]

6. Wagner, S.M.; Bode, C. An Empirical Examination of Supply Chain Performance along Several Dimensions of Risk. J. Bus. Logist. 2008, 29, 307-325. [CrossRef]

7. Kilubi, I. The strategies of supply chain risk management-A synthesis and classification. Int. J. Logist. Res. Appl. 2016, 19, 604-629. [CrossRef]

8. Craighead, C.W.; Blackhurst, J.; Rungtusanatham, M.J.; Handfield, R.B. The Severity of Supply Chain Disruptions: Design Characteristics and Mitigation Capabilities. Decis. Sci. 2007, 38, 131-156. [CrossRef]

9. Zhao, L.; Huo, B.; Sun, L.; Zhao, X. The impact of supply chain risk on supply chain integration and company performance: A global investigation. Supply Chain Manag. Int. J. 2013, 18, 115-131. [CrossRef]

10. Jajja, M.S.S.; Chatha, K.A.; Farooq, S. Impact of supply chain risk on agility performance: Mediating role of supply chain integration. Int. J. Prod. Econ. 2018, 205, 118-138. [CrossRef]

11. Kauppi, K.; Longoni, A.; Caniato, F.; Kuula, M. Managing country disruption risks and improving operational performance: Risk management along integrated supply chains. Int. J. Prod. Econ. 2016, 182, 484-495. [CrossRef]

12. Wiengarten, F.; Humphreys, P.; Gimenez, C.; McIvor, R. Risk, risk management practices, and the success of supply chain integration. Int. J. Prod. Econ. 2016, 171, 361-370. [CrossRef]

13. Brusset, X.; Teller, C. Supply chain capabilities, risks, and resilience. Int. J. Prod. Econ. 2017, 184, 59-68. [CrossRef]

14. Manuj, I.; Mentzer, J.T. Global supply chain risk management strategies. Int. J. Phys. Distrib. Logist. Manag. 2008, 38, 192-223. [CrossRef]

15. Knemeyer, A.M.; Zinn, W.; Eroglu, C. Proactive planning for catastrophic events in supply chains. J. Oper. Manag. 2008, 27, 141-153. [CrossRef]

16. Kumar Sharma, S.; Bhat, A. Supply chain risk management dimensions in Indian automobile industry: A cluster analysis approach. Bench. Int. J. 2014, 21, 1023-1040. [CrossRef]

17. Caniato, F.; Golini, R.; Kalchschmidt, M.G.M. The effect of global supply chain configuration on the relationship between supply chain improvement programs and performance. Int. J. Prod. Econ. 2013, 143, 285-293. [CrossRef]

18. Tang, C.S. Perspectives in supply chain risk management. Int. J. Prod. Econ. 2006, 103, 451-488. [CrossRef]

19. Wu, T.; Blackhurst, J.; Chidambaram, V. A model for inbound supply risk analysis. Comput. Ind. 2006, 57, 350-365. [CrossRef]

20. Tian, Q.; Guo, W. Reconfiguration of manufacturing supply chains considering outsourcing decisions and supply chain risks. J. Manuf. Syst. 2019, 52, 217-226. [CrossRef]

21. Asgary, A.; Ozdemir, A.I.; Özyürek, H. Small and Medium Enterprises and Global Risks: Evidence from Manufacturing SMEs in Turkey. Int. J. Disaster Risk Sci. 2020, 11, 59-73. [CrossRef]

22. Ethirajan, M.; Arasu, M.T.; Kandasamy, J.; Kek, V.; Nadeem, S.P.; Kumar, A. Analysing the risks of adopting circular economy initiatives in manufacturing supply chains. Bus. Strateg. Environ. 2021, 30, 204-236. [CrossRef]

23. Shishodia, A.; Sharma, R.; Rajesh, R.; Munim, Z.H. Supply chain resilience: A review, conceptual framework and future research. Int. J. Logist. Manag. 2021. [CrossRef]

24. Rajesh, R. A novel advanced grey incidence analysis for investigating the level of resilience in supply chains. Ann. Oper. Res. 2020, 308, 441-490. [CrossRef]

25. Byrne, P.M. Impact and ubiquity: Two reasons to proactively manage risk. Logist. Manag. 2007, 46, $24-25$.

26. Fabbe-Costes, N.; Jahre, M. Supply chain integration and performance: A review of the evidence. Int. J. Logist. Manag. 2008, 19, 130-154. [CrossRef]

27. Pagell, M. Understanding the factors that enable and inhibit the integration of operations, purchasing and logistics. J. Oper. Manag. 2004, 22, 459-487. [CrossRef]

28. Kim, Y.H.; Schoenherr, T. The Effects of Supply Chain Integration on the Cost Efficiency of Contract Manufacturing. J. Supply Chain Manag. 2018, 54, 42-64. [CrossRef]

29. Flynn, B.B.; Huo, B.; Zhao, X. The impact of supply chain integration on performance: A contingency and configuration approach. J. Oper. Manag. 2010, 28, 58-71. [CrossRef] 
30. Swink, M.; Narasimhan, R.; Wang, C. Managing beyond the factory walls: Effects of four types of strategic integration on manufacturing plant performance. J. Oper. Manag. 2006, 25, 148-164. [CrossRef]

31. Lai, K.-H.; Wong, C.W.; Cheng, T. Bundling digitized logistics activities and its performance implications. Ind. Mark. Manag. 2010, 39, 273-286. [CrossRef]

32. Chen, I.J.; Paulraj, A. Towards a theory of supply chain management: The constructs and measurements. J. Oper. Manag. 2004, 22, 119-150. [CrossRef]

33. Kim, S.W. An investigation on the direct and indirect effect of supply chain integration on firm performance. Int. J. Prod. Econ. 2009, 119, 328-346. [CrossRef]

34. Mishra, D.; Sharma, R.; Kumar, S.; Dubey, R. Bridging and buffering: Strategies for mitigating supply risk and improving supply chain performance. Int. J. Prod. Econ. 2016, 180, 183-197. [CrossRef]

35. Wong, C.Y.; Boon-Itt, S. The influence of institutional norms and environmental uncertainty on supply chain integration in the Thai automotive industry. Int. J. Prod. Econ. 2008, 115, 400-410. [CrossRef]

36. Zhao, G.; Feng, T.; Wang, D. Is more supply chain integration always beneficial to financial performance? Ind. Mark. Manag. 2015, 45, 162-172. [CrossRef]

37. Qi, Y.; Huo, B.; Wang, Z.; Yeung, H.Y.J. The impact of operations and supply chain strategies on integration and performance. Int. J. Prod. Econ. 2017, 185, 162-174. [CrossRef]

38. Vanalle, R.M.; Lucato, W.C.; Ganga, G.M.D.; Alves Filho, A.G. Risk management in the automotive supply chain: An exploratory study in Brazil. Int. J. Prod. Res. 2019, 58, 783-799. [CrossRef]

39. Talluri, S.; Narasimhan, R.; Nair, A. Vendor performance with supply risk: A chance-constrained DEA approach. Int. J. Prod. Econ. 2006, 100, 212-222. [CrossRef]

40. Wagner, S.; Neshat, N. Assessing the vulnerability of supply chains using graph theory. Int. J. Prod. Econ. 2010, 126, 121-129. [CrossRef]

41. Tsai, M.; Liao, C.; Han, C. Risk perception on logistics outsourcing of retail chains: Model development and empirical veri-fication in Taiwan. Supply Chain Manag. Int. J. 2008, 13, 415-424. [CrossRef]

42. Johnson, N.; Elliott, D.; Drake, P. Exploring the role of social capital in facilitating supply chain resilience. Supply Chain Manag. Int. J. 2013, 18, 324-336. [CrossRef]

43. Alcaide-Muñoz, C.; Pintado, A.B.; De Cerio, J.M.-D. Manufacturing strategy process: The role of shop-floor communication. Manag. Decis. 2018, 56, 1581-1597. [CrossRef]

44. Tuncel, G.; Alpan, G. Risk assessment and management for supply chain networks: A case study. Comput. Ind. 2010, 61, 250-259. [CrossRef]

45. Gaudenzi, B.; Borghesi, A. Managing risks in the supply chain using the AHP method. Int. J. Logist. Manag. 2006, 17, 114-136. [CrossRef]

46. Naor, M.; Linderman, K.; Schroeder, R. The globalization of operations in Eastern and Western countries: Unpacking the relationship between national and organizational culture and its impact on manufacturing performance. J. Oper. Manag. 2009, 28, 194-205. [CrossRef]

47. Morita, M.; Machuca, J.A.D.; Pérez Díez de los Ríos, J.L. Integration of product development capability and supply chain capability: The driver for high performance adaptation. Int. J. Prod. Econ. 2018, 200, 68-82. [CrossRef]

48. Alfalla-Luque, R.; Machuca, J.A.; Marin-Garcia, J.A. Triple-A and competitive advantage in supply chains: Empirical research in developed countries. Int. J. Prod. Econ. 2018, 203, 48-61. [CrossRef]

49. Arend, R.J.; Wisner, J.D. Small business and supply chain management: Is there a fit? J. Bus. Ventur. 2005, 20, 403-436. [CrossRef]

50. Crum, M.; Nelson, T.; de Borst, J.; Byrnes, P. The use of cluster analysis in entrepreneurship research: Review of past research and future directions. J. Small Bus. Manag. 2020, 1-40. [CrossRef]

51. Jain, A.K. Data clustering: 50 years beyond K-means. Pattern Recognit. Lett. 2009, 31, 651-666. [CrossRef]

52. European Commission. User Guide to the SME Definition; Publications Office of the European Union: Luxembourg, 2015.

53. Gligor, D.M.; Holcomb, M.C.; Feizabadi, J. An exploration of the strategic antecedents of firm supply chain agility: The role of a firm's orientations. Int. J. Prod. Econ. 2016, 179, 24-34. [CrossRef]

54. Cheng, Y.; Chaudhuri, A.; Farooq, S. Interplant coordination, supply chain integration, and operational performance of a plant in a manufacturing network: A mediation analysis. Supply Chain Manag. An Int. J. 2016, 21, 550-568. [CrossRef]

55. Chen, J.; Sohal, A.S.; Prajogo, D. Supply chain operational risk mitigation: A collaborative approach. Int. J. Prod. Res. 2013, 51, 2186-2199. [CrossRef]

56. McNally, R.C.; Griffin, A. A measure and initial test of managers' perceptions of relationship marketing in inter-organizational exchanges. J. Acad. Mark. Sci. 2007, 35, 382-397. [CrossRef]

57. Choi, K.; Narasimhan, R.; Kim, S.W. Postponement strategy for international transfer of products in a global supply chain: A system dynamics examination. J. Oper. Manag. 2012, 30, 167-179. [CrossRef]

58. Lau, A.K.W.; Tang, E.; Yam, R.C.M. Effects of Supplier and Customer Integration on Product Innovation and Performance: Empirical Evidence in Hong Kong Manufacturers. J. Prod. Innov. Manag. 2010, 27, 761-777. [CrossRef]

59. Chaudhuri, A.; Boer, H.; Taran, Y. Supply chain integration, risk management and manufacturing flexibility. Int. J. Oper. Prod. Manag. 2018, 38, 690-712. [CrossRef] 
60. Qazi, A.; Dickson, A.; Quigley, J.; Gaudenzi, B. Supply chain risk network management: A Bayesian belief network and ex-pected utility based approach for managing supply chain risks. Int. J. Prod. Econ. 2018, 196, 24-42. [CrossRef]

61. Macdonald, J.R.; Zobel, C.W.; Melnyk, S.A.; Griffis, S.E. Supply chain risk and resilience: Theory building through structured experiments and simulation. Int. J. Prod. Res. 2018, 56, 4337-4355. [CrossRef]

62. Zsidisin, G.A.; Ellram, L.M. An agency theory investigation of supply risk management. J. Supply Chain Manag. 2003, 39, 15-27. [CrossRef]

63. Hopp, W.J.; Spearman, M.L. Factory Physics; Irwin/McGraw-Hill: Boston, MA, USA, 2000.

64. Cohen, M.A.; Kunreuther, H. Operations risk management: Overview of Paul Kleindorfer's contributions. Prod. Oper. Manag. 2007, 16, 525-541. [CrossRef]

65. Lee, H.L. Aligning Supply Chain Strategies with Product Uncertainties. Calif. Manag. Rev. 2002, 44, 105-119. [CrossRef]

66. Paulraj, A.; Chen, I.J. Environmental Uncertainty and Strategic Supply Management: A Resource Dependence Perspective and Performance Implications. J. Supply Chain Manag. 2007, 43, 29-42. [CrossRef]

67. Munir, M.; Jajja, M.S.S.; Chatha, K.A.; Farooq, S. Supply chain risk management and operational performance: The enabling role of supply chain integration. Int. J. Prod. Econ. 2020, 227, 107667. [CrossRef]

68. Das, A.; Narasimhan, R.; Talluri, S. Supplier integration-Finding an optimal configuration. J. Oper. Manag. 2005, 24, 563-582 [CrossRef]

69. Riley, J.M.; Klein, R.; Miller, J.; Sridharan, V. How internal integration, information sharing, and training affect supply chain risk management capabilities. Int. J. Phys. Distrib. Logist. Manag. 2016, 46, 953-980. [CrossRef]

70. Teece, D.J.; Pisano, G.; Shuen, A. Dynamic capabilities and strategic management. Strateg. Manag. J. 1997, 18, 509-533. [CrossRef]

71. Rosenzweig, E.D.; Roth, A.V.; Dean, J.W. The influence of an integration strategy on competitive capabilities and business performance: An exploratory study of consumer products manufacturers. J. Oper. Manag. 2003, 21, 437-456. [CrossRef]

72. Sahay, B. Supply chain collaboration: The key to value creation. Work Study 2003, 52, 76-83. [CrossRef]

73. Hu, W.; Shou, Y.; Kang, M.; Park, Y. Risk management of manufacturing multinational corporations: The moderating effects of international asset dispersion and supply chain integration. Supply Chain Manag. Int. J. 2019, 25, 61-76. [CrossRef]

74. Meznar, M.B.; Nigh, D. Buffer or bridge? Environmental and organizational determinants of public affairs activities in American firms. Acad. Manag. J. 1995, 38, 975-996.

75. Bode, C.; Wagner, S.; Petersen, K.; Ellram, L.M. Understanding Responses to Supply Chain Disruptions: Insights from Information Processing and Resource Dependence Perspectives. Acad. Manag. J. 2011, 54, 833-856. [CrossRef]

76. Lee, H. The triple-A supply chain. Harv. Bus. Rev. 2004, 82, 102-113. [PubMed]

77. Childerhouse, P.; Towill, D.R. Arcs of supply chain integration. Int. J. Prod. Res. 2011, 49, 7441-7468. [CrossRef] 